\title{
SCGB3A1 gene DNA methylation status is associated with breast cancer in Egyptian female patients
}

\author{
Azhar Mohamed Nomair ${ }^{1 *}$, Sanaa Shawky Ahmed ${ }^{2}$, Ayman Farouk Mohammed ${ }^{3}$, Hazem El Mansy ${ }^{4}$ and \\ Hanan Mohamed Nomeir ${ }^{5}$
}

\begin{abstract}
Background: In recent years, hypermethylation of gene promoters has emerged as one of the fundamental mechanisms for the inactivation of tumor suppressor genes and has a potential role in the early detection of breast cancer. The present study is a case-control study aimed to quantify the methylation levels in the promoters of secretoglobin 3A1 (SCGB3A1), and ataxia-telangiectasia mutated (ATM) genes and evaluate their relation to clinicopathological features of the tumor in a cohort of Egyptian female patients with breast cancer.

Methods: Genomic deoxyribonucleic acid (DNA) was extracted from 100 tissue samples, 50 breast cancer tissues and 50 adjacent non-cancerous breast tissues, then, it was subjected to bisulfite conversion. The converted DNA was amplified by real-time PCR; then, pyrosequencing was performed to quantify DNA methylation levels in four CpG sites in ATM and SCGB3A1 gene promoters. The methylation data were presented as the percentage of average methylation of all the observed CpG sites and were calculated for each sample and each gene.

Results: The percentage of DNA methylation of the SCGB3A1 promoter was significantly higher in the tumor group than in the normal group $(P=0.001)$. However, a non-statistical significance difference was found in the DNA methylation percentage of the ATM promoter in the tumor group compared to the normal group $(P=0.315)$. The SCGB3A1 promoter methylation frequency was significantly associated with estrogen receptors (ER) and progesterone receptors (PR) positive tumors, lymph node metastasis, and lymphovascular invasion. However, no association was found between ATM methylation status and the different clinicopathological features of the tumor.

Conclusions: The findings of this work showed that the SCGB3A1 promoter methylation was significantly higher in the tumor group and was significantly associated with different clinicopathologic features in breast cancer. It may be considered as a suitable biomarker for diagnosis and prognosis. However, the promoter methylation levels of the ATM gene in breast cancer cases were unable to distinguish between breast cancer tissues and adjacent normal tissues, and there is no evidence that epigenetic silencing by ATM methylation has a role in breast cancer pathogenesis.
\end{abstract}

Keywords: Breast cancer, DNA methylation, Pyrosequencing, SCGB3A1, ATM

\footnotetext{
* Correspondence: azhar.mohmd@alexu.edu.eg; azhar.mohmd@yahoo.com 'Department of Chemical Pathology, Medical Research Institute, Alexandria University, P.B. 21561, 165 El-Horreya Street, El Hadara, Alexandria, Egypt Full list of author information is available at the end of the article
}

\section{Springer Open}

(c) The Author(s). 2021 Open Access This article is licensed under a Creative Commons Attribution 4.0 International License, which permits use, sharing, adaptation, distribution and reproduction in any medium or format, as long as you give appropriate credit to the original author(s) and the source, provide a link to the Creative Commons licence, and indicate if changes were made. The images or other third party material in this article are included in the article's Creative Commons licence, unless indicated otherwise in a credit line to the material. If material is not included in the article's Creative Commons licence and your intended use is not permitted by statutory regulation or exceeds the permitted use, you will need to obtain permission directly from the copyright holder. To view a copy of this licence, visit http://creativecommons.org/licenses/by/4.0/. 


\section{Background}

Epigenetic changes are inherited DNA alterations that affect the function and expression of genes without changing the DNA sequence. The mechanisms of epigenetic alterations include DNA methylation, alterations in chromatin condensation, histone modifications, and RNA interference [1].

DNA methylation comprises the addition of a methyl group by the DNA methyltransferase enzyme in the 5' position of cytosine in a cytosine-guanine (CpG) dinucleotide, which aggregates in the promoter region leading to a densely packed chromatin and transcriptional gene silencing. It affects regulator genes that cover a wide range of cellular pathways. Abnormal DNA methylation patterns have been associated with almost all types of cancer, including breast cancer [2].

Breast cancer is the most common neoplasm among women all over the world, and there are more than 1, 300,000 newly diagnosed cases every year [3]. Despite early detection and improvement in its management, its mortality increases annually, accounting for $14 \%$ of the total cancer deaths [4]. It is considered a complex multifactorial disease. It has been widely established to be caused by an interaction between environmental and genetic factors [5]. There is increasing evidence that hypermethylation of tumor-related genes may have added to the pathogenesis of breast cancer in recent years [6].

Secretoglobin 3A1 (SCGB3A1) gene, also called high in normal-1 $(H I N-1)$ is a gene located at chromosome $5 \mathrm{q} 35.3$ and encodes 104 amino acids protein, which is a member of the secretoglobin family that consists of small secretory proteins [7]. The SCGB3A1 gene is highly expressed in the epithelial cells of normal lung, uterus, prostate, and breast [8]. It is involved in regulating epithelial cell proliferation, differentiation, and morphogenesis. Thus, its abnormal expression may result in the development of malignant phenotype in human tumors [9]. The aberrant methylation of the SCGB3A1 gene was displayed in multiple human cancer types at an early stage of malignant transformation, including breast cancer [10].

The ataxia-telangiectasia mutated $(A T M)$ gene which is located at 11q22.3 codes for a protein kinase; a member of the 3-kinase phosphatidylinositol family, that shows a significant role in the activation of cellular responses to double-stranded DNA breaks through downstream phosphorylation of principal players in the response pathways of DNA damage which include BRCA1, p53, and Chk2 [11]. It plays a central role in maintaining the integrity of the genome by activating the checkpoints of the cell cycle and promoting the repair of double-strand breaks of DNA. It is involved in recognizing the damaged DNA, recruitment of repair proteins, signaling to cell cycle checkpoints, transcriptional regulation, and apoptosis activation [12]. ATM promoter hypermethylation has been observed in a variety of cancers, including cancer colon, head and neck squamous cell carcinoma, glioma, and gastric lymphoma. However, data on the methylation status in breast tumors showed contradictory results [13-16].

Pyrosequencing is a quantitative sequencing-bysynthesis approach that provides a rapid, highthroughput means of quantifying methylation levels globally and at regulatory elements of methylationsensitive genes [17]. It is a fast, reproducible, and easyto-use method to analyze not only $\mathrm{CpG}$-rich but also CpG-poor regions, making it possible to define a threshold discriminating hypomethylation or hypermethylation and differences in DNA methylation among various tissue types [18].

To better understand the role of DNA methylation and its relation to clinicopathological features in breast cancer, we used the pyrosequencing technique to assess the methylation status in two candidate genes, SCGB3A1 and $A T M$, which are known to have significance in the regulation of cellular processes and to evaluate their association with the clinicopathological features in breast cancer cases. This could lead to a better understanding of the tumorigenesis process and possibly improve the diagnosis and treatment of this cancer.

\section{Methods}

\section{Study population and sample collection}

A total of 50 female patients with primary breast cancer who underwent surgery at the Department of Surgery at the Medical Research Institute Hospital, from December 2018 to June 2019 were consecutively enrolled in this study. The surgical intervention was conservative breast surgery (96\%) or modified radical mastectomy (4\%).

All female patients were recruited after their diagnosis with primary breast cancer based on the standard clinical, radiological, and histological parameters. We did not specify certain age groups or tumor characteristics. Patients with a previous history of neo-adjuvant chemotherapy, radiotherapy, or hormonal therapy were excluded from the study. Also, patients with a history of other cancers, acute medical or surgical conditions, were excluded. Informed consent was collected from all patients. The study was approved by the ethics committee of the Medical Research Institute (Ref. IORG 0008812), which is following the Declaration of Helsinki code of ethics for research involving humans.

Before surgery, all patients underwent full history taking, thorough physical examination, fine-needle aspiration cytology, or ultrasound-guided core biopsy from the breast mass for preoperative pathological examination. Also, mammography, breast ultrasound, pelvi- 
abdominal ultrasound, chest X-ray, and bone scan were done.

Total 100 fresh tissue specimens, 50 from the excised breast cancer tissues and 50 from the adjacent normal tissues after leaving a clearly defined safety margin, were collected during the operation. Serial $5 \mu \mathrm{m}$ thick paraffin sections from all cases were subjected to routine hematoxylin and eosin staining to assess the histologic tumor type, tumor grade, lymphovascular invasion, and lymph node metastasis. The collected fresh samples were stored immediately at $-80{ }^{\circ} \mathrm{C}$ until use.

Breast cancer hormonal assay in the form of ER, PR, and human epidermal growth factor receptor 2 (HER2/ neu) were evaluated using immunohistochemistry. The clinicopathological parameters were assessed, including the histopathology of the tumor, pathological grade, and the clinical staging, which was performed according to the tumor-node-metastasis (TNM) classification system.

\section{Detection of methylation status of SCGB3A1 and ATM genes}

\section{Genomic DNA extraction and bisulfite treatment}

DNA extraction was performed from $25 \mathrm{mg}$ tissue samples using QIAamp DNA Mini Kit (Qiagen, Germany. Cat No: 51304) following manufacture instructions. The concentration and purity of the extracted DNA were assessed using the Thermo Scientific NanoDrop ${ }^{\text {тм }} 1000$ spectrophotometer.

Five microliters of the extracted DNA samples was bisulfite-treated to convert all unmethylated cytosine residues to uracil, while 5-methylcytosine residues stay unaffected, using EpiTect Fast Bisulfite Conversion Kit (Qiagen, Germany Cat No. 59824). The modified DNA was then stored at $-20{ }^{\circ} \mathrm{C}$ for further analysis.

\section{DNA amplification}

The converted DNA was amplified by PCR using the PyroMark PCR Kit (Qiagen, Cat No. 978703) according to the manual instructions. The final volume of each PCR reaction mix was $25 \mu \mathrm{L}$. Each reaction consisted of $12.5 \mu \mathrm{L}$ PyroMark PCR master mix $(2 \times), 2.5 \mu \mathrm{L}$ CoralLoad concentrate $(10 \times), 2.5 \mu \mathrm{L}$ sodium bisulfite-treated DNA, $1.25 \mu \mathrm{L}(200 \mathrm{nM})$ final concentrations of each primer, and 5.0 $\mu \mathrm{L}$ RNase-free water. The primers for PCR amplification and pyrosequencing, one of them being biotinylated, were purchased from Qiagen, Germany; PyroMark CpG Assays (Cat No. 978746). The PCR conditions consisted of initial denaturation at $95{ }^{\circ} \mathrm{C}$ for 15 min, 45 cycles of denaturation at $94{ }^{\circ} \mathrm{C}$ for $30 \mathrm{~s}$, annealing at $56{ }^{\circ} \mathrm{C}$ for $30 \mathrm{~s}$, and extension at $72{ }^{\circ} \mathrm{C}$ for $30 \mathrm{~s}$, then a final extension at $72{ }^{\circ} \mathrm{C}$ for $10 \mathrm{~min}$. The PCR products were separated on agarose gel electrophoresis to confirm successful amplification.

\section{Pyrosequencing methylation analyses}

Quantitative DNA methylation analysis of the two studied genes was performed using the Pyromark Q24 Instrument (Qiagen, Germany). PyroMark Gold Q24 Reagents Kit (Qiagen, Cat No. 971802) which contained all enzymes, substrates, and nucleotides needed in the pyrosequencing cascade was used. A pyrosequencing reaction mix consisted of $40 \mu \mathrm{L}$ PyroMark Binding buffer (Cat No. 979306), $1 \mu \mathrm{L}$ streptavidin-coated Sepharose beads, and $29 \mu \mathrm{L}$ nuclease-free water was prepared for each reaction before adding $10 \mu \mathrm{L}$ biotinylated PCR products. The beads were captured with the vacuum tool on the PyroMark Vacuum Workstation. They were thoroughly washed and subsequently denatured generating single-stranded DNA suitable for pyrosequencing. This template DNA was released into the pyrosequencing reaction plate containing $22.5 \mu \mathrm{L}$ annealing buffer and $2.5 \mu \mathrm{L}$ sequencing primer $(0.3 \mu \mathrm{M})$ for each reaction. The primers used in pyrosequencing are summarized in Table 1. After primer annealing, the plate was placed into the PyroMark instrument, and the sequencing reaction was started. The plates were prepared for pyrosequencing according to the manufacturer's protocol. Only data that passed appropriate quality control thresholds were included for analysis. Pyrosequencing results were evaluated using the PyroMark Q24 version: 2.0.8 software (Qiagen, Germany). The methylation percentage at each $\mathrm{CpG}$ site was calculated from the ratio of heights of a cytosine peak (methylated signal) divided by the sum of cytosine and thymine peaks (methylated and unmethylated signals) and displayed on a pyrogram. An example of the pyrogram produced by pyrosequencing of the promoters of the two genes was shown in Figs. 1 and 2. Methylation levels were presented as the percentage of average methylation of all the measured CpG sites and then, were calculated for each sample and each gene [19].

\section{Statistical methods}

All statistical calculations were done using the IBM SPSS software package version 20.0. (Armonk, NY: IBM Corp). The Kolmogorov-Smirnov test was used to verify the normality of distribution. Wilcoxon signed-rank test was used for abnormally distributed quantitative variables to compare between two related samples. Comparisons between groups for categorical variables were evaluated using the chi-square test (Fisher's exact or Monte Carlo correction). The significance of the obtained results was judged at $P \leq 0.05$.

The median value of the percentage of DNA methylation levels of normal tissue samples of each gene was used as a cut-off point. Therefore, the frequencies of DNA hypermethylation were represented as the percentage of samples with methylation levels above or equal to 
Table 1 The primers used in pyrosequencing

\begin{tabular}{|c|c|c|c|c|c|c|}
\hline $\begin{array}{l}\text { Gene } \\
\text { symbol }\end{array}$ & $\begin{array}{l}\text { Entrez } \\
\text { Gene ID }\end{array}$ & $\begin{array}{l}\text { Qiagen } \\
\text { product code }\end{array}$ & Pyrosequencing primers* & Chromosomal location & $\begin{array}{l}\text { Number of } \\
\text { CpG sites }\end{array}$ & $\begin{array}{l}\text { PCR product } \\
\text { size }\end{array}$ \\
\hline ATM & $4863 / 472$ & $\begin{array}{l}\text { Hs_NPAT/ATM_ } \\
\text { 01_PM } \\
\text { (PM00153622) }\end{array}$ & $\begin{array}{l}\text { CGCGGACGCGGGAWGGAGGGTTAT } \\
\text { TGGACCCGGC }\end{array}$ & $\begin{array}{l}\text { Chromosome 11, BP 1080931X- } \\
\text { 1080932XX }\end{array}$ & 4 & $203 \mathrm{bp}$ \\
\hline $\begin{array}{l}\text { SCGB3A1/ } \\
\text { HIN-1 }\end{array}$ & 92304 & $\begin{array}{l}\text { Hs_SCGB3A1_- } \\
01 \text { 1_PM } \\
\text { (PM0022687) }\end{array}$ & $\begin{array}{l}\text { GGGGCGTTITTCTGTCTTCGAAACTA } \\
\text { GCCTCGACGC }\end{array}$ & $\begin{array}{l}\text { Chromosome 5, BP } \\
\text { 1800190XX-1800190XX }\end{array}$ & 4 & $90 \mathrm{bp}$ \\
\hline
\end{tabular}

*Primer sequences were adopted from PyroMark Assay Database

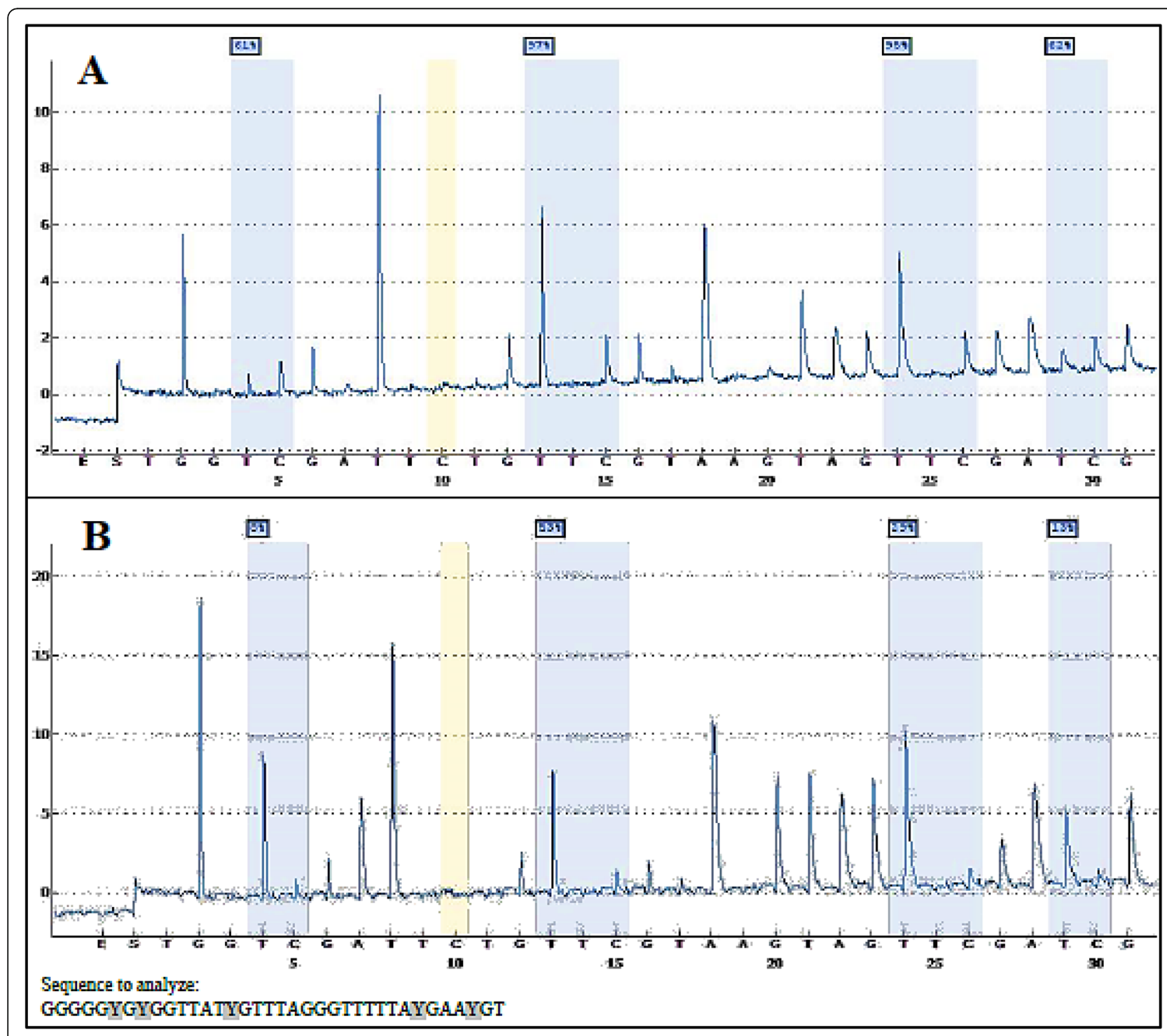

Fig. 1 An example of a pyrogram produced by pyrosequencing of the SCGB3A1 gene promoter. A Tumor group. B Normal group. The gray highlights mark the tested $\mathrm{CPG}$ sites and the percentage methylation readings. X-axis, dispensation order; Y-axis, relative light intensity 


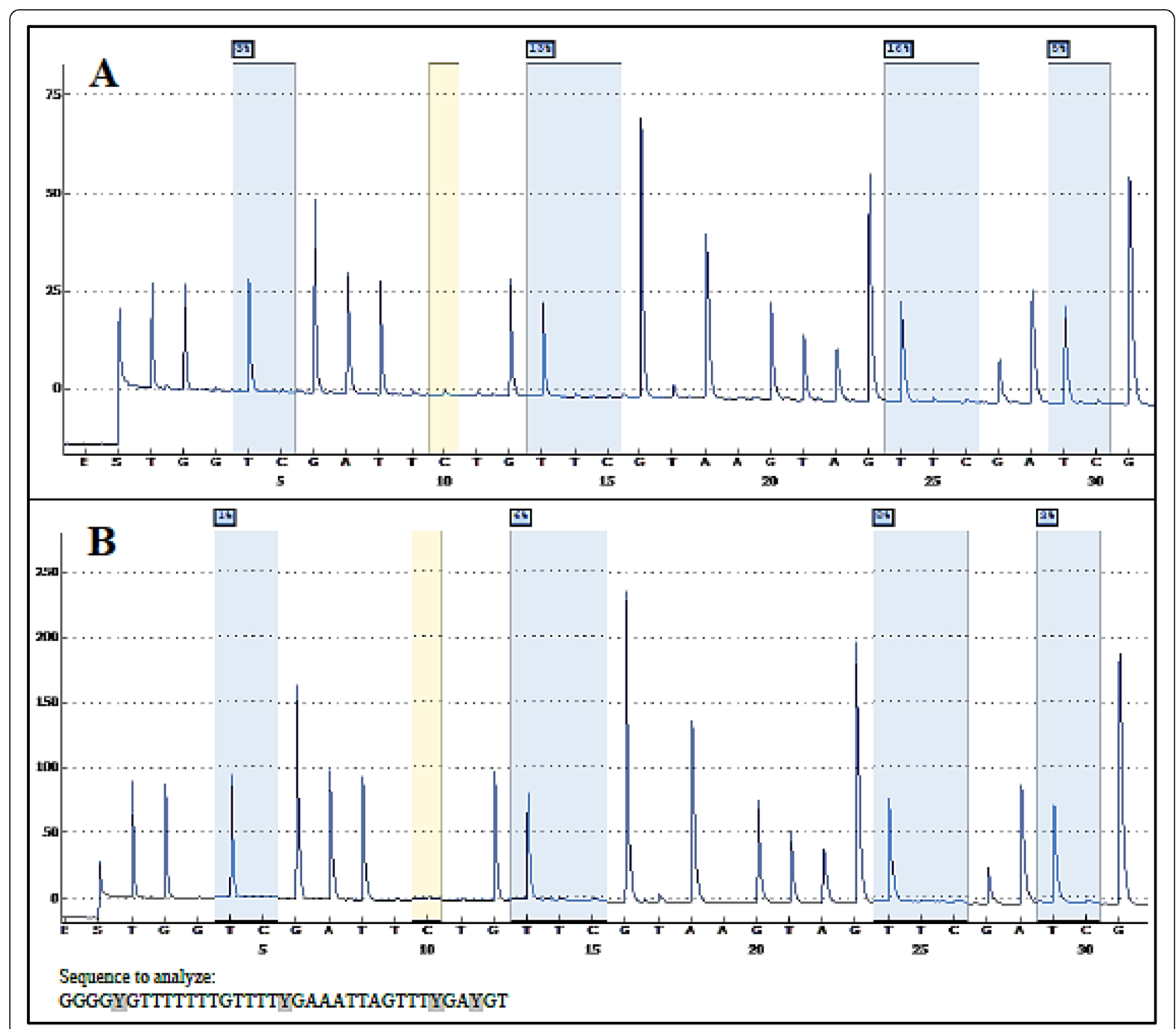

Fig. 2 An example of a pyrogram produced by pyrosequencing of the ATM gene promoter. A Tumor group. B Normal group. The gray highlights mark the tested CpG sites and the percentage methylation readings. X-axis, dispensation order; Y-axis, relative light intensity

the cut-off value for each gene, which was $43.4 \%$ for the SCGB3A1 gene, and $8.4 \%$ for the ATM gene.

\section{Results}

Bisulfite pyrosequencing was used to quantify DNA methylation levels of SCGB3A1 and ATM genes in 50 samples of breast cancer tissues (tumor group) and in the corresponding 50 samples of adjacent normal tissues (normal group).

The clinical data of the patients and the tumor characteristics are summarized in Table 2. The age of the involved subjects was above 50 years in $50 \%$ of cases. Sixty-four percent were in the post-menopausal state. Positive ER was encountered in $72 \%$ of patients, and positive PR was $64 \%$, while HER2/neu receptors were found positive in $78 \%$ of cases. Regarding the molecular type, $22 \%$ were luminal A, 50\% were luminal B, and $28 \%$ were HER2-enriched (Table 2).

SCGB3A1 and ATM promoter methylation were assessed in the two studied groups. The DNA methylation percentage of SCGB3A1 promoter was significantly higher in the tumor group compared to the normal group $(P=0.001)$ (Table 3 ) (Fig. 3$)$. However, a nonstatistical significance difference was found in the DNA methylation percentage of the ATM promoter in the tumor group compared to the normal group $(P=0.315)$. The frequency of SCGB3A1 promoter methylation was significantly associated with ER, and PR positive tumors 
Table 2 Patients and tumor characteristics $(N=50)$

\begin{tabular}{|c|c|c|}
\hline Variables & No. & $\%$ \\
\hline \multicolumn{3}{|l|}{ Age (years) } \\
\hline$\leq 50$ & 25 & 5 \\
\hline$>50$ & 25 & \\
\hline \multicolumn{3}{|l|}{ Family history } \\
\hline Yes & 23 & 4 \\
\hline No & 27 & \\
\hline \multicolumn{3}{|l|}{ Menstrual history } \\
\hline Post menopause & 32 & \\
\hline Pre menopause & 18 & \\
\hline \multicolumn{3}{|l|}{ Focality } \\
\hline Unifocal & 44 & \\
\hline Multifocal & 6 & \\
\hline \multicolumn{3}{|l|}{ Tumor size $(\mathrm{cm})$} \\
\hline$\leq 2$ & 25 & \\
\hline$>2$ & 25 & \\
\hline \multicolumn{3}{|c|}{ Histopathological type } \\
\hline IDC & 44 & \\
\hline ILC & 6 & \\
\hline \multicolumn{3}{|l|}{ Pathological grade } \\
\hline Grade I & 7 & \\
\hline Grade ॥ & 29 & 5 \\
\hline Grade III & 14 & \\
\hline
\end{tabular}

Lymph vascular invasion

$\begin{array}{ll}\text { Positive } & 43 \\ \text { Negative } & 7\end{array}$

\section{$\%$}

$\mathrm{N}$ metastasis

Positive

Negative

TNM stage

IA

$\|A+\| B$

III

ER

HER2/neu

Positive

Negative

Molecular type

IDC invasive ductal carcinoma, ILC invasive lobular carcinoma, $L N$ lymph node, TNM tumor-node-metastasis classification system, ER estrogen receptors, PR progesterone receptors, HER2/neu human epidermal growth factor receptor 2 
( $P=0.005$, and 0.022 respectively), lymph node metastasis $(P=0.015)$, and lymphovascular invasion $(P=0.012)$ (Table 4). However, no association was found between ATM methylation frequency and the different clinicopathological features of the tumor.

\section{Discussion}

Breast cancer is the most common cancer associated with high mortality rates among women worldwide [3]. The silencing of tumor suppressor genes by hypermethylation is an essential epigenetic mechanism in breast tumorigenesis [20]. Epigenetic alterations differ from genetic ones primarily in their greater frequency, incomplete reversibility, and their location in fixed genome regions. They affect the early stages of the carcinogenic process, nominating them as promising markers in early diagnosis [21]. In the present study, we assessed the promoter methylation of two tumor suppressor genes, SCGB3A1 and ATM, in breast cancer tissues and adjacent normal tissues, and we evaluated their association with the clinicopathological features of the tumor.

The current findings demonstrated that DNA methylation levels of the $S C G B 3 A 1$ promoter were significantly higher in the tumor group compared to the normal group $(P=0.001)$. In accordance with previous results, Cho et al. [22] showed significant hypermethylation of the SCGB3A1 gene in the tumor tissues compared to the adjacent normal tissues. Vavoulidis et al. [23] found that the SCGB3A1 promoter was hypermethylated in $82.1 \%$ of all malignant cases, in contrast with the low frequencies in patients negative for neoplasia or with benign breast lesions. In addition, Feng et al. [9] found that SCGB3A1 was densely methylated in cancer cell lines and was frequently methylated in breast cancer tissues with a $49 \%$ positive rate. Park et al. [24] concluded that the CpG island methylation of the SCGB3A1 gene is an early event that predominantly occurs during the preinvasive stage of breast cancer and accumulates with breast cancer progression. Moreover, Gurioli et al. [25] reported that the SCGB3A1 methylation levels gradually increased from low and intermediate in healthy noncancerous tissue to high in cancerous tissue. Another study demonstrated that a three-gene panel including the SCGB3A1 gene could distinguish between breast ductal carcinoma in situ and normal breast tissues with $96 \%$ sensitivity and $87 \%$ specificity [26].

SCGB3A1 is expressed with an increased amount in the normal terminal duct lobular unit in the mammary gland, and it has a role in regulating the proliferation, differentiation, and morphogenesis of epithelial cells [27]. It was reported that reintroduction of SCGB3A1 into breast cancer cell line inhibited cell growth. This indicated that SCGB3A1 is a tumor suppressor gene that is deactivated with high frequency in the early stages of breast tumorigenesis. Its promoter hypermethylation may be associated with transcriptional gene suppression, possibly leading to uncontrolled cell growth [28]. The results of the current study agreed with these findings and supported the role of SCGB3A1 promoter methylation in cancer pathogenesis. We suggest that it could be an important characteristic as a diagnostic biomarker.

The status of the hormone receptors is an important prognostic factor in breast cancer patients. It is also considered a predictive marker for the response to hormonal therapy [9]. In this study, we demonstrated a significant association between SCGB3A1 methylation

Table 3 DNA methylation percentage of ATM and SCGB3A1 promoters in the studied groups

\begin{tabular}{|c|c|c|c|c|c|}
\hline & \multicolumn{2}{|c|}{ Tumor group $(n=50)$} & \multicolumn{2}{|c|}{ Normal group $(n=50)$} & \multirow[t]{2}{*}{$P$} \\
\hline & Mean \pm SD & Median (IQR) & Mean \pm SD & $\overline{\text { Median (IQR) }}$ & \\
\hline \multicolumn{6}{|l|}{ ATM (\%) } \\
\hline CpG_1 & $2.9 \pm 1.8$ & $2(3)$ & $3.4 \pm 2.2$ & $3(3)$ & 0.194 \\
\hline CpG_2 & $8.3 \pm 4$ & $7.5(7)$ & $9.6 \pm 4.3$ & $10(6)$ & 0.356 \\
\hline CpG_3 & $11.4 \pm 5.2$ & $10(9)$ & $12 \pm 4.8$ & $12.5(8)$ & 0.550 \\
\hline CpG_4 & $4.6 \pm 2.2$ & $5(3)$ & $5.1 \pm 2.5$ & $4.5(4)$ & 0.495 \\
\hline Average CpG sites & $6.8 \pm 2.8$ & $6.3(4.8)$ & $7.5 \pm 3$ & $8.4(5.3)$ & 0.315 \\
\hline \multicolumn{6}{|l|}{ SCGB3A1 (\%) } \\
\hline CpG_1 & $32.3 \pm 20.7$ & $22.5(37)$ & $23.9 \pm 17.1$ & $22.5(22)$ & $0.001^{*}$ \\
\hline CpG_2 & $78.6 \pm 23.5$ & $89.5(47)$ & $69.9 \pm 24.6$ & $72.5(39)$ & $0.010^{*}$ \\
\hline CpG_3 & $55.1 \pm 24.8$ & $49.5(49)$ & $48 \pm 22.8$ & $45(33)$ & $0.012^{*}$ \\
\hline CpG_4 & $29.1 \pm 14.9$ & $24(29)$ & $20 \pm 15.3$ & $20(23)$ & $<0.001^{*}$ \\
\hline Average CpG sites & $48.8 \pm 16.6$ & $49.3(26.5)$ & $40.4 \pm 16.3$ & $43.4(27.8)$ & $0.001^{*}$ \\
\hline
\end{tabular}

$P$ value, compares the studied groups using Wilcoxon signed ranks; ${ }^{*}$, Statistical significance at $P \leq 0.05 ; S D$ standard deviation, $I Q R$ interquartile range. CpG_1, CpG_2, CpG_3, and CpG_4 stand for the four CpG sites studied in each assay 

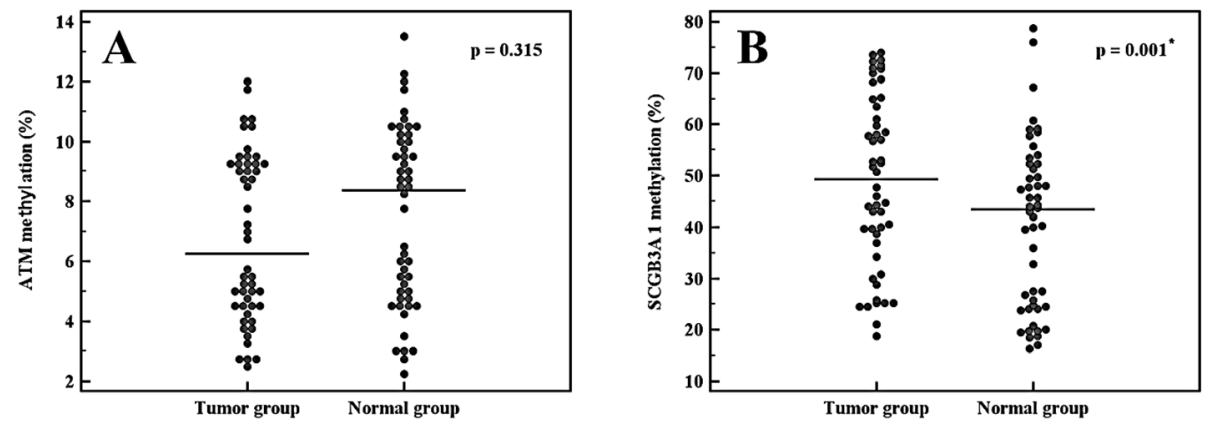

Fig. 3 Comparison of the methylation levels of ATM (A) and SCGB3A1 (B) genes in tumor samples and paired normal samples. Horizontal lines provided median methylation levels of each group

frequency and ER, and PR positive tumors $(P=0.005$, and $P=0.022$ respectively). This study and others [29$31]$ provided an evidence for the association between epigenetic changes and hormonal receptor regulation in breast cancer. In addition, Conway et al. [30] reported that $S C G B 3 A 1$ promoter was highly methylated in the luminal A type of breast tumor and linked the aberrant methylation events with exposures that modulate the risk of tumor subtypes. On the other hand, previous studies showed no consistent associations with hormonal status [23, 24]. This disagreement could be related to differences in laboratory or statistical methodology, the sample size or clinical status of the subjects.

In line with previous studies $[32,33]$, the frequency of $S C G B 3 A 1$ promoter methylation was significantly associated with LN metastasis $(P=0.015)$ and lymphovascular invasion $(P=0.012)$. This finding indicates that SCGB3A1 methylation can be used as a prognostic marker for breast cancer.

In the present work, we found no association between SCGB3A1 methylation frequency and the age $(P=$ $0.564)$, tumor size $(P=0.083)$, histopathological type $(P$ $=0.672)$, pathological grade $(P=0.123)$, or TNM staging $(P=0.061)$. Similar results were detected by Feng et al. [9] and Callahan et al. [31]. On the other hand, previous studies reported significant differences in tumor size [22, 29,32 ], the grade [32], and stage of the tumor [26].

ATM phosphorylate a large number of downstream proteins after its activation by double-stranded DNA breaks. These proteins include those involved in the cell-cycle checkpoint arrest, DNA repair like BRCA1 and RAD51, and apoptosis such as p53. It also modulates networks not immediately engaged in DNA repair like insulin-like growth factors and other metabolic and stress-response pathways. Subsequently, silencing of the ATM gene expression may hinder the repair of the damaged DNA and augment cancer development [34]. Previous studies reported that diminished ATM expression occurs in a significant portion of breast tumors $[35,36]$.
These findings led us to hypothesize the link between epigenetic events and the reduced ATM function in sporadic breast cancer. However, the reported results about the role of DNA hypermethylation as a mechanism for ATM protein expression deregulation in breast tumors are conflicting.

In this work, a non-significant difference was found in ATM methylation levels in the tumor group compared to the normal group $(P=0.315)$. Similarly, Cao et al. [13] used two different assays and reported the same results. Krasteva et al. [21] demonstrated a normal methylation profile of the ATM promoter in all studied cases. Other studies [37-39] come to the same conclusion, implying that ATM promoter hypermethylation is not involved in the neoplastic pathways of sporadic breast cancer.

On the other hand, previous studies have demonstrated ATM hypermethylation in breast cancer patients. Flanagan et al. [16] showed significant hypermethylation of one intragenic repetitive element in breast cancer cases when compared to matched controls, and Brennan et al. [40] found a strong association of ATM methylation levels in the family group, but the CpG sites they investigated were in the gene body or intragenic region not in the promoter. Other studies [2, 41] showed promoter hypermethylation for the ATM gene in cancer tissue samples compared to normal tissues. The differences in sample size or methylation methodology could explain this distinct methylation pattern.

In our study, we found no correlation between $A T M$ promoter DNA methylation and the various clinicopathological features of the tumor. This result agreed with Cao et al. [13] who displayed the same finding. On the other hand, Begam et al. [2] has detected an association between ATM promoter methylation and the age, tumor size, and advanced stage of the disease.

The current study results did not support the contribution of the ATM promoter hypermethylation in the neoplastic pathways of breast cancer. However, such an 
Table 4 The associations between ATM and SCGB3A1 methylation frequency and the clinicopathological characteristics of the studied patients

\begin{tabular}{|c|c|c|c|c|c|c|}
\hline \multirow{3}{*}{ Variables } & \multicolumn{2}{|l|}{ ATM } & \multirow{3}{*}{$P$} & \multicolumn{2}{|l|}{ SCGB3A1 } & \multirow{3}{*}{$P$} \\
\hline & $\begin{array}{l}<8.4 \\
(n=29)\end{array}$ & $\begin{array}{l}\geq 8.4 \\
(n=21)\end{array}$ & & $\begin{array}{l}<43.4 \\
(n=20)\end{array}$ & $\begin{array}{l}\geq 43.4 \\
(n=30)\end{array}$ & \\
\hline & n (\%) & n (\%) & & n (\%) & n (\%) & \\
\hline \multicolumn{7}{|l|}{ Age (years) } \\
\hline$\leq 50$ & $12(48)$ & $13(52)$ & 0.152 & $9(36)$ & $16(64)$ & 0.564 \\
\hline$>50$ & $17(68)$ & $8(32)$ & & $11(44)$ & $14(56)$ & \\
\hline \multicolumn{7}{|l|}{ Family history } \\
\hline Yes & $14(60.9)$ & $9(39.1)$ & 0.704 & $11(47.8)$ & $12(52.2)$ & 0.297 \\
\hline No & $15(55.6)$ & $12(44.4)$ & & $9(33.3)$ & $18(66.7)$ & \\
\hline \multicolumn{7}{|l|}{ Menstrual history } \\
\hline Post menopause & $17(53.1)$ & $15(46.9)$ & 0.352 & $12(37.5)$ & $20(62.5)$ & 0.630 \\
\hline Pre menopause & $12(66.7)$ & $6(33.3)$ & & $8(44.4)$ & $10(55.6)$ & \\
\hline \multicolumn{7}{|l|}{ Focality } \\
\hline Unifocal & $24(54.5)$ & $20(45.5)$ & $0.380^{\mathrm{FE}}$ & $20(45.5)$ & $24(54.5)$ & $0.069^{\mathrm{FE}}$ \\
\hline Multifocal & $5(83.3)$ & $1(16.7)$ & & $0(0)$ & $6(100)$ & \\
\hline \multicolumn{7}{|l|}{ Tumor size (cm) } \\
\hline$<2$ & $17(68)$ & $8(32)$ & 0.152 & $7(28)$ & $18(72)$ & 0.083 \\
\hline$\geq 2$ & $12(48)$ & $13(52)$ & & $13(52)$ & $12(48)$ & \\
\hline \multicolumn{7}{|l|}{ Histopathological type } \\
\hline IDC & $25(56.8)$ & $19(43.2)$ & $1.000^{\mathrm{FE}}$ & $17(38.6)$ & $27(61.4)$ & $0.672^{\mathrm{FE}}$ \\
\hline ILC & $4(66.7)$ & $2(33.3)$ & & $3(50)$ & $3(50)$ & \\
\hline \multicolumn{7}{|l|}{ Pathological grade } \\
\hline Early $(G|+G| l)$ & $21(58.3)$ & $15(41.7)$ & 0.939 & $12(33.3)$ & $24(66.7)$ & 0.123 \\
\hline Late (GIII) & $8(57.1)$ & $6(42.9)$ & & $8(57.1)$ & $6(42.9)$ & \\
\hline Lymph vascular invasion & $27(62.8)$ & $16(37.2)$ & $0.115^{\mathrm{FE}}$ & $14(32.6)$ & $29(67.4)$ & $0.012^{* \mathrm{FE}}$ \\
\hline LN metastasis & $19(67.9)$ & $9(32.1)$ & 0.111 & $7(25)$ & $21(75)$ & $0.015^{*}$ \\
\hline \multicolumn{7}{|l|}{ TNM stage } \\
\hline $\mathrm{A}$ & $4(44.4)$ & $5(55.6)$ & $0.709^{\mathrm{MC}}$ & $6(66.7)$ & $3(33.3)$ & $0.061^{\mathrm{MC}}$ \\
\hline$\|A+\| B$ & $19(59.4)$ & $13(40.6)$ & & $13(40.6)$ & $19(59.4)$ & \\
\hline III & $6(66.7)$ & $3(33.3)$ & & $1(11.1)$ & $8(88.9)$ & \\
\hline ER positive & $21(58.3)$ & $15(41.7)$ & 0.939 & $10(27.8)$ & $26(72.2)$ & $0.005^{*}$ \\
\hline PR positive & $18(56.3)$ & $14(43.8)$ & 0.738 & $9(28.1)$ & $23(71.9)$ & $0.022^{*}$ \\
\hline HER2/neu positive & $22(56.4)$ & $17(43.6)$ & $0.741^{\mathrm{FE}}$ & $18(46.2)$ & $21(53.8)$ & $0.163^{\mathrm{FE}}$ \\
\hline \multicolumn{7}{|l|}{ Molecular type } \\
\hline Luminal A & $7(63.6)$ & $4(36.4)$ & $0.741^{\mathrm{FE}}$ & $2(18.2)$ & $9(81.8)$ & $0.163^{\mathrm{FE}}$ \\
\hline Luminal B & $14(56)$ & $11(44)$ & 0.774 & $8(32)$ & $17(68)$ & 0.248 \\
\hline HER2 enriched & $8(57.1)$ & $6(42.9)$ & 0.939 & $10(71.4)$ & $4(28.6)$ & $0.005^{*}$ \\
\hline
\end{tabular}

IDC invasive ductal carcinoma, ILC invasive lobular carcinoma, $L N$ lymph node, TNM tumor-node-metastasis classification system, ER estrogen receptors, $P R$ progesterone receptors, HER2/neu human epidermal growth factor receptor 2

$P$ value, compares the studied groups using $X^{2}$ Chi-square test, MC Monte Carlo, FE Fisher's exact tests; ${ }^{*}$, statistical significance at $P \leq 0.05$

association could not be excluded. So, more studies to validate these results are needed. Other epigenetic mechanisms may have a role in the functional activity of ATM in the tumorigenesis process. Moreover, the molecular pattern of the ATM gene, and its protein expression, which are lacking in our study, are complementary, and both should be considered to be done in further research.

Various environmental factors such as nutrition, stress, working habits, smoking, alcohol consumption, and 
lifestyle trigger epigenetic mechanisms, including DNA methylation, so that genetic methylation profile is different among populations [42, 43]. This study focused on the Egyptian population with their geographic, environmental, and lifestyle characteristics.

Other factors should also be considered when interpreting our results, the relatively small sample size, the different CpG sites, and the technique used for quantification, although we used the sensitive pyrosequencing assay for methylation analysis.

Larger sample sizes from different populations and ethnicities, as well as more studied CpG sites, are recommended to shed more light on the role of SCGB3A1 and ATM promoters' methylation in breast cancer development and the potential use of these genes as biomarkers for breast cancer detection. The current study is also limited by the lack of correlation of our results with the molecular pattern of both genes and their protein expression, so additional research involving more insight on these parameters is recommended in the future, which may clarify more details and help to get a clearer picture on these molecular processes and breast cancer development.

\section{Conclusions}

In conclusion, $S C G B 3 A 1$ promoter methylation was significantly higher in the tumor group and was significantly associated with different clinicopathologic features of the tumor. It was associated with ER and PR positive tumors, LN metastasis, and lymphovascular invasion. These findings provided an empirical evidence that aberrant SCGB3A1 promoter methylation may contribute to the pathogenesis of breast cancer and may have a role in distinguishing between malignant disease and normal. Thus, it may be considered as a suitable biomarker for diagnosis and prognosis. However, the promoter methylation levels of the ATM gene in breast cancer cases were unable to differentiate between breast cancer tissues and adjacent normal tissues. No association was found between the DNA methylation status of the ATM gene promoter and the clinicopathological features of the tumor. More investigations are recommended to validate these results and give more insight into the role of both genes in breast cancer development, diagnosis, and prognosis.

\footnotetext{
Abbreviations

SCGB3A1: Secretoglobin 3A1; ATM: Ataxia-telangiectasia mutated; CpG: Cytosine-guanine; HIN-1: High in normal-1; IDC: Invasive ductal carcinoma; ILC: Invasive lobular carcinoma; LN: Lymph node; TNM: Tumornode-metastasis classification system; ER: Estrogen receptors; PR: Progesterone receptors; HER2/neu: Human epidermal growth factor receptor 2; TNM: Tumor-node-metastasis classification system
}

\section{Authors' contributions}

AMN performed the design of the study, made the literature review, carried out the molecular genetic studies, analyzed and interpreted the patient data, and was a major contributor in writing the manuscript. SSA performed the immunohistochemistry and pathological examination of the samples and revised the manuscript. AFM provided the surgical specimens and revised the manuscript. HEM participated in writing and revision of the manuscript. HMN participated in the design of the study, carried out the molecular genetic studies, and revised the manuscript. The authors read and approved the final manuscript.

\section{Funding}

Not applicable

\section{Availability of data and materials}

The datasets used and analyzed during the current study are available on request.

\section{Declarations}

\section{Ethics approval and consent to participate}

The study was approved by the local ethics committee of the Medical Research Institute, Alexandria University (reference number: IORG 0008812), in accordance with The Code of Ethics of the World Medical Association (Declaration of Helsinki) for research involving humans, and written informed consents were obtained from all included patients before the acquisition of the tissue specimens.

\section{Consent for publication \\ Not applicable}

\section{Competing interests}

The authors declare that they have no competing interests.

\section{Author details}

${ }^{1}$ Department of Chemical Pathology, Medical Research Institute, Alexandria University, P.B. 21561, 165 El-Horreya Street, El Hadara, Alexandria, Egypt.

${ }^{2}$ Department of Pathology, Medical Research Institute, Alexandria University, Alexandria, Egypt. ${ }^{3}$ Department of Clinical and Experimental Surgery, Medical Research Institute, Alexandria University, Alexandria, Egypt. ${ }^{4}$ Department of Cancer Management and Research, Medical Research Institute, Alexandria University, Alexandria, Egypt. ${ }^{5}$ Department of Medical Biochemistry, Faculty of Medicine, Alexandria University, Alexandria, Egypt.

Received: 2 February 2021 Accepted: 25 June 2021

Published online: 23 July 2021

\section{References}

1. Feinberg AP (2018) The key role of epigenetics in human disease prevention and mitigation. N Engl J Med. 378(14):1323-1334. https://doi. org/10.1056/NEJMra1402513

2. Begam N, Jamil K, Raju SG (2017) Promoter hypermethylation of the ATM gene as a novel biomarker for breast cancer. Asian Pac J Cancer Prev 18(11): 3003-3009. https://doi.org/10.22034/APJCP.2017.18.11.3003

3. Ferlay J, Soerjomataram I, Dikshit R, Eser S, Mathers C, Rebelo M, Parkin DM, Forman D, Bray F (2015) Cancer incidence and mortality worldwide: sources, methods, and major patterns in GLOBOCAN 2012. Int J Cancer. 136(5):E359E386. https://doi.org/10.1002/ijc.29210

4. Malvezzi M, Carioli G, Bertuccio P, Boffetta P, Levi F, La Vecchia C et al (2019) European cancer mortality predictions for the year 2019 with focus on breast cancer. Ann Oncol. 30(5):781-787. https://doi.org/10.1093/annonc/ $\mathrm{mdz051}$

5. Nelson HD, Zakher B, Cantor A, Fu R, Griffin J, O'Meara ES, Buist DS, Kerlikowske K, van Ravesteyn N, Trentham-Dietz A, Mandelblatt JS, Miglioretti DL (2012) Risk factors for breast cancer for women aged 40 to 49 years: a systematic review and meta-analysis. Ann Intern Med. 156(9):635648. https://doi.org/10.7326/0003-4819-156-9-201205010-00006

6. Hill VK, Ricketts C, Bieche I, Vacher S, Gentle D, Lewis C, Maher ER, Latif F (2011) Genome-wide DNA methylation profiling of CpG islands in breast cancer identifies novel genes associated with tumorigenicity. Cancer Res. 71(8):2988-2999. https://doi.org/10.1158/0008-5472.CAN-10-4026 
7. Tomita T, Kimura S (2008) Regulation of mouse Scgb3a1 gene expression by NF-Y and association of CpG methylation with its tissue-specific expression. BMC Mol Biol. 9(1):5. https://doi.org/10.1186/1471-2199-9-5

8. Dai D, Dong XH, Cheng ST, Zhu G, Guo XL (2014) Aberrant promoter methylation of $\mathrm{HIN}-1$ gene may contribute to the pathogenesis of breast cancer: a meta-analysis. Tumour Biol. 35(8):8209-8216. https://doi.org/10.1 007/s13277-014-2055-1

9. Feng W, Shen L, Wen S, Rosen DG, Jelinek J, Hu X, Huan S, Huang M, Liu J, Sahin AA, Hunt KK, Bast RC Jr, Shen Y, Issa JPJ, Yu Y (2007) Correlation between CpG methylation profiles and hormone receptor status in breast cancers. Breast Cancer Res. 9(4):R57. https://doi.org/10.1186/bcr1762

10. Ahlquist T, Lind GE, Costa VL, Meling Gl, Vatn M, Hoff GS, Rognum TO, Skotheim Rl, Thiis-Evensen E, Lothe RA (2008) Gene methylation profiles of normal mucosa, and benign and malignant colorectal tumors identify early onset markers. Mol Cancer. 7(1):94. https://doi.org/10.1186/1476-4598-7-94

11. Goldgar DE, Healey S, Dowty JG, Da Silva L, Chen X, Spurdle AB et al (2011) Rare variants in the ATM gene and risk of breast cancer. Breast Cancer Res. 13(4):R73. https://doi.org/10.1186/bcr2919

12. Kermi C, Aze A, Maiorano D (2019) Preserving genome integrity during the early embryonic DNA replication cycles. Genes (Basel). 10(5):398. https://doi. org/10.3390/genes10050398

13. Cao X, Tang Q, Holland-Letz T, Gündert M, Cuk K, Schott S, Heil J, Golatta M, Sohn C, Schneeweiss A, Burwinkel B (2018) Evaluation of promoter methylation of RASSF1A and ATM in peripheral blood of breast cancer patients and healthy control individuals. Int J Mol Sci. 19(3):900. https://doi. org/10.3390/ijms19030900

14. Lam K, Pan K, Linnekamp JF, Medema JP, Kandimalla R (2016) DNA methylation based biomarkers in colorectal cancer: a systematic review. Biochim Biophys Acta. 1866(1):106-120. https://doi.org/10.1016/j.bbcan.2016. 07.001

15. Gaździcka J, Gołąbek K, Strzelczyk JK, Ostrowska Z (2020) Epigenetic modifications in head and neck cancer. Biochem Genet. 58(2):213-244. https://doi.org/10.1007/s10528-019-09941-1

16. Flanagan JM, Munoz-Alegre $M$, Henderson $S$, Tang $T$, Sun $P$, Johnson $N$, Fletcher O, dos Santos Silva I, Peto J, Boshoff C, Narod S, Petronis A (2009) Gene-body hypermethylation of ATM in peripheral blood DNA of bilateral breast cancer patients. Hum Mol Genet. 18(7):1332-1342. https://doi.org/1 0.1093/hmg/ddp033

17. Delaney C, Garg SK, Yung R (2015) Analysis of DNA methylation by pyrosequencing. methods. Mol Biol 1343:249-264. https://doi.org/10.1007/ 978-1-4939-2963-4_19

18. Roessler J, Lehmann U (2015) Quantitative DNA methylation analysis by Pyrosequencing ${ }^{\oplus}$. methods. Mol Biol 1315:175-188. https://doi.org/10.1007/ 978-1-4939-2715-9_13

19. Poulin M, Zhou JY, Yan L, Shioda T (1856) Pyrosequencing methylation analysis. Methods Mol Biol. 2018:283-296. https://doi.org/10.1007/978-1-493 9-8751-1_17

20. Delmonico L, Silva Magalhães Costa MA, Gomes RJ, De Oliveira Vieira P, ABP DS, Fournier MV et al (2020) Methylation profiling in promoter sequences of ATM and CDKN2A (p14ARF/p16INK4a) genes in blood and cfDNA from women with impalpable breast lesions. Oncol Lett. 19(4):3003-3010. https:// doi.org/10.3892/ol.2020.11382

21. Krasteva ME, Antov GG, Gospodinova ZI, Angelova SG, Nacheva MB, Georgieva El et al (2014) Aberrant promoter methylation in p53 and ATM genes was not associated with sporadic breast carcinogenesis in Bulgarian patients. J. BioSci. Biotech. 3(2):105-109

22. Cho YH, Yazici H, Wu HC, Terry MB, Gonzalez K, Qu M, Dalay N, Santella RM (2010) Aberrant promoter hypermethylation and genomic hypomethylation in tumor, adjacent normal tissues and blood from breast cancer patients. Anticancer Res. 30(7):2489-2496

23. Vavoulidis E, Petousis S, Margioula Siarkou C, Mareti E, Kougioumtsidou N, Symeonidou M, Loufopoulos PD, Daniilidis A, Chatzikyriakidou A, Lambropoulos A, Zepiridis L, Dinas K (2020) Molecular evaluation of a multiplex methylation panel for epigenetic analysis of FNAB samples from Greek patients with suspicious breast lesions. J BUON. 25(5):2244-2254

24. Park SY, Kwon HJ, Lee HE, Ryu HS, Kim SW, Kim JH, Kim IA, Jung N, Cho NY, Kang GH (2011) Promoter CpG island hypermethylation during breast cancer progression. Virchows Arch. 458(1):73-84. https://doi.org/10.1007/ s00428-010-1013-6

25. Gurioli G, Salvi S, Martignano F, Foca F, Gunelli R, Costantini M, Cicchetti G, de Giorgi U, Sbarba PD, Calistri D, Casadio V (2016) Methylation pattern analysis in prostate cancer tissue: identification of biomarkers using an MSMLPA approach. J Transl Med. 14(1):249. https://doi.org/10.1186/s12967-01 6-1014-6

26. Lee JS, Fackler MJ, Teo WW, Lee JH, Choi C, Park MH et al (2008) Quantitative promoter hypermethylation profiles of ductal carcinoma in situ in North American and Korean women: potential applications for diagnosis. Cancer Biol Ther. 7(9):1398-1406. https://doi.org/10.4161/cbt.7.9.6425

27. Goldstein NS, Vicini FA, Kestin LL, Thomas M (2000) Differences in the pathologic features of ductal carcinoma in situ of the breast based on patient age. Cancer. 88(11):2553-2560. https://doi.org/10.1002/1097-0142 (20000601)88:11<2553::aid-cncr18>3.0.co;2-v

28. Fackler MJ, McVeigh M, Evron E, Garrett E, Mehrotra J, Polyak K, Sukumar S, Argani P (2003) DNA methylation of RASSF1A, HIN-1, RAR-beta, Cyclin D2 and Twist in in situ and invasive lobular breast carcinoma. Int J Cancer. 107(6):970-975. https://doi.org/10.1002/ijc.11508

29. Xu J, Shetty PB, Feng W, Chenault C, Bast RC Jr, Issa JP et al (2012) Methylation of HIN-1, RASSF1A, RIL and CDH13 in breast cancer is associated with clinical characteristics, but only RASSF1A methylation is associated with outcome. BMC Cancer. 12(1):243. https://doi.org/10.1186/14 71-2407-12-243

30. Conway K, Edmiston SN, May R, Kuan PF, Chu H, Bryant C, Tse CK, SwiftScanlan T, Geradts J, Troester MA, Millikan RC (2014) DNA methylation profiling in the Carolina Breast Cancer Study defines cancer subclasses differing in clinicopathologic characteristics and survival. Breast Cancer Res. 16(5):450. https://doi.org/10.1186/s13058-014-0450-6

31. Callahan $\mathrm{CL}$, Wang Y, Marian C, Weng DY, Eng KH, Tao MH, Ambrosone CB, Nie J, Trevisan M, Smiraglia D, Edge SB, Shields PG, Freudenheim JL (2016) DNA methylation and breast tumor clinicopathological features: the Western New York Exposures and Breast Cancer (WEB) study. Epigenetics. 11(9):643-652. https://doi.org/10.1080/15592294.2016.1192735

32. Hafez MM, Al-Shabanah OA, Al-Rejaie SS, Al-Harbi NO, Hassan ZK, Alsheikh A et al (2015) Increased hypermethylation of glutathione S-transferase P1, DNA-binding protein inhibitor, death associated protein kinase and paired box protein-5 genes in triple-negative breast cancer Saudi females. Asian Pac J Cancer Prev. 16(2):541-549. https://doi.org/10.7314/apjcp.2015.16.2.541

33. Feng W, Orlandi R, Zhao N, Carcangiu ML, Tagliabue E, Xu J, Bast RC Jr, Yu Y (2010) Tumor suppressor genes are frequently methylated in lymph node metastases of breast cancers. BMC Cancer. 10(1):378. https://doi.org/10.11 86/1471-2407-10-378

34. Maréchal A, Zou L (2013) DNA damage sensing by the ATM and ATR kinases. Cold Spring Harb Perspect Biol. 5(9):a012716. https://doi.org/10.11 01/cshperspect.a012716

35. Abdel-Fatah TM, Arora A, Alsubhi N, Agarwal D, Moseley PM, Perry C et al (2014) Clinicopathological significance of ATM-Chk2 expression in sporadic breast cancers: a comprehensive analysis in large cohorts. Neoplasia. 16(11): 982-991. https://doi.org/10.1016/j.neo.2014.09.009

36. Cuatrecasas M, Santamaria G, Velasco M, Camacho E, Hernandez L, Sanchez $M$ et al (2006) ATM gene expression is associated with differentiation and angiogenesis in infiltrating breast carcinomas. Histol Histopathol 21(2):149156. https://doi.org/10.14670/HH-21.149

37. Dejeux E, Rønneberg JA, Solvang H, Bukholm I, Geisler S, Aas T, Gut IG, Børresen-Dale AL, Lønning P, Kristensen VN, Tost J (2010) DNA methylation profiling in doxorubicin treated primary locally advanced breast tumours identifies novel genes associated with survival and treatment response. Mol Cancer. 9(1):68. https://doi.org/10.1186/1476-4598-9-68

38. Allinen M, Peri L, Kujala S, Lahti-Domenici J, Outila K, Karppinen SM, Launonen V, Winqvist R (2002) Analysis of 11q21-24 loss of heterozygosity candidate target genes in breast cancer: indications of TSLC1 promoter hypermethylation. Genes Chromosomes Cancer. 34(4):384-389. https://doi. org/10.1002/gcc.10079

39. Treilleux I, Chapot B, Goddard S, Pisani P, Angèle S, Hall J (2007) The molecular causes of low ATM protein expression in breast carcinoma; promoter methylation and levels of the catalytic subunit of DNA-dependent protein kinase. Histopathology. 51(1):63-69. https://doi.org/10.1111/j.1365-2 559.2007.02726.x

40. Brennan K, Garcia-Closas M, Orr N, Fletcher O, Jones M, Ashworth A, Swerdlow A, Thorne H, KConFab Investigators, Riboli E, Vineis P, Dorronsoro M, Clavel-Chapelon F, Panico S, Onland-Moret NC, Trichopoulos D, Kaaks R, Khaw KT, Brown R, Flanagan JM (2012) Intragenic ATM methylation in peripheral blood DNA as a biomarker of breast cancer risk. Cancer Res. 72(9):2304-2313. https://doi.org/10.1158/0008-5472.CAN-11-3157 
41. Vo QN, Kim WJ, Cvitanovic L, Boudreau DA, Ginzinger DG, Brown KD (2004) The ATM gene is a target for epigenetic silencing in locally advanced breast cancer. Oncogene 23(58):9432-9437. https://doi.org/10.1038/sj.onc.1208092 Erratum in: Oncogene. 2005; 24(11):1964

42. Fraser HB, Lam LL, Neumann SM, Kobor MS (2012) Population-specificity of human DNA methylation. Genome Biol. 13(2):R8. https://doi.org/10.1186/ gb-2012-13-2-r8

43. Galanter JM, Gignoux CR, Oh SS, Torgerson D, Pino-Yanes M, Thakur N, Eng C, Hu D, Huntsman S, Farber HJ, Avila PC, Brigino-Buenaventura E, LeNoir MA, Meade K, Serebrisky D, Rodríguez-Cintrón W, Kumar R, RodríguezSantana JR, Seibold MA, Borrell LN, Burchard EG, Zaitlen N (2017) Differential methylation between ethnic sub-groups reflects the effect of genetic ancestry and environmental exposures. Elife. 6:e20532. https://doi.org/10 7554/eLife.20532

\section{Publisher's Note}

Springer Nature remains neutral with regard to jurisdictional claims in published maps and institutional affiliations.

\section{Submit your manuscript to a SpringerOpen ${ }^{\circ}$ journal and benefit from:}

- Convenient online submission

- Rigorous peer review

- Open access: articles freely available online

- High visibility within the field

- Retaining the copyright to your article

Submit your next manuscript at $\boldsymbol{\nabla}$ springeropen.com 